\title{
A Mobile Web Application Enhancing Knowledge and Providing Health Services Concerning Sexually Transmitted Diseases and Unplanned Pregnancy Prevention Among Akha Adolescents in Chiangrai Province, Northern Thailand
}

Suphaphan Chansiri ( $\nabla$ suphaphan.cha@mfu.ac.th )

Mae Fah Luang University https://orcid.org/0000-0002-2916-0839

Charoenchai Wongwatkit

Mae Fah Luang University

Research Article

Keywords: Mobile web application, Sexually transmitted diseases, Unplanned pregnancy, Akha, Adolescents

Posted Date: February 28th, 2022

DOI: https://doi.org/10.21203/rs.3.rs-1367597/v1

License: (1) This work is licensed under a Creative Commons Attribution 4.0 International License.

Read Full License 


\section{Abstract}

Background: Akha adolescents in Chiang Rai lack knowledge about safe sex, the severity of sexually transmitted diseases, and unplanned pregnancy. This research aimed to develop innovative applications to serve as an important tool for enhancing knowledge and understanding of sexual health.

Methods: The study consisted of three phases. The first phase was a survey of the needs of Akha adolescents on Doi Mae Salong and Doi Wawee in Chiang Rai Province, using an exploratory qualitative research method. A semi-structured interview was used with a total of 48 subjects in both the formal and non-formal education system. Data were analyzed by content analysis. The second phase was the designing and development of the mobile web application prototype which was given to a group of 37 people, both males and females to try out. The third phase was to test the users' knowledge improvement and a questionnaire survey of users' satisfaction and opinions about the mobile web application using a sample of 108 users. Data were analyzed using descriptive statistics: frequency; percentage; mean; and standard deviation including a paired sample t-test.

Results: The findings revealed a statistical significance ( $p \leq 0.001)$ in the improvement of users' knowledge (both males and females) between the pretest $(\bar{x}=4.15)$ and the posttest $(\bar{x}=7.23)$. Users' satisfactions were also revealed with their impressions in 3 areas: 1 ) learning; 2 ) ease of use; 3 ) information display. The users found the mobile web application was useful, interesting, and attractive.

Conclusions: This innovative application can increase knowledge and practices and prevent pregnancies and sexually transmitted diseases. It can be used in various learning contexts.

\section{Background}

At present, high rates of pregnancy and childbirth in adolescents with sexually transmitted infections are on the rise according to the report of the Bureau of Epidemiology [1, 2]. In Thailand, between 2012 and 2016 , the numbers of the adolescents and young adults aged 15-24 years with sexually transmitted diseases increased from 93.4 to 143.4 people per one hundred thousand people of the same age group. In the worst case, in 2015, around 4,100 children up to 15 years old were infected with HIV. The majority of these cases were due to unsafe sex [3].

In Chiang Rai, adolescent mothers aged 15-19 gave an average of 34.7 births per one thousand of the female population in the same age group [4]. Teen pregnancy affects both the mother and the baby. In the mother, it can cause pain during pregnancy and premature birth [5] and create high blood pressure in the gestational and postpartum periods [6]. Babies born to adolescent mothers are about 1.2-1.6 times more likely to be born prematurely than infants born to mothers aged 20-24. Infants born to adolescent mothers are less likely to have a birth weight of less than 2500 grams than infants who are born from adolescent mothers, 1.1-1.2 times of the childbirths of mothers aged 20-24 [6]. This leads to a higher rate of stress, depression, abortion, and suicide 7]. This is a major problem in Thai society, today. While all 
sectors are trying to solve the problem, the rate of sexually transmitted infections, pregnancies and childbirths are still relatively high among the adolescent population.

\section{Sexually transmitted diseases through pregnancies and childbirths in young adults}

The Department of Disease Control, Bureau of Epidemiology (2017) reported the increase of the sexually transmitted diseases in pregnancies and childbirths of young adults as follow [2]. Between 2012 and 2016 , the number of sexually transmitted infections among young adults aged 15-24 years increased from 93.4 to 143.4 per one hundred thousand people of the same age group. It affected young adults study life because they might have to drop out of the schools with the worst case of HIV infection [3]. Therefore, Thai health care providers realized that sexually transmitted diseases were health problems which needed to be addressed.

\section{Technologies and applications for sexual health}

Over the past decade, technology has played a huge role in enhancing knowledge, providing health services and promoting and facilitating sexual health. There are 177 sexual health websites related to the use of condoms, sexually transmitted infections, HIV infections, etc. Most of these traditional websites are of poor quality [8]. Previous research studies on technology found that young adults preferred to communicate through text messaging rather than e-mail. The studies also revealed that social media played an important role in preventing high-risk behaviors. Thus, there should be direct links to young sexual health-related groups or organizations [9].

In the United States, it was found that new digital media could help promote sexual health among young adults such as to delay the first experiences of sex, motivate users of social networks, and help educate them about HIV, sexually transmitted infections, and pregnancy [10].

Digital media technology, interactive video, text messaging, and the internet are used in the prevention of sexually transmitted infections and HIV among young people aged 11-29 years [11]. Recently, social media has been active in promoting safe sex. Technology could replace the old style of learning and directly affect behavior, as well as reduce the risk of contracting diseases [12]. The opportunities and challenges of social media with a focus on adolescent and youth health care with young adults being able to access applications continuously. In addition, social media can offer direct advice on any disease or conditions that occurs, as well as enhance the provision of relevant information [13]. Another study on social media and the prevention of sexual risk behaviors found that users were more likely to use condoms [14].

A "Girl Talk" application was developed to teach young women about sexual health. It has been found that users have significantly increased their knowledge on topics such as relationships and sexually transmitted infections [15]. Applications in various forms such as responding to learning and users being able to access and can be used anywhere and anytime [16-18]. 
However, previous studies have revealed a lack of appropriate interactive devices to advise, assist, and provide services related to adolescent sexual health problems, especially for Chiang Rai's ethnic adolescents, such as Akha hill tribe teenagers [19]. The researcher is interested in developing innovative applications providing knowledge-building and health services to prevent sexually transmitted diseases and unplanned pregnancies in Chiang Rai's Akha adolescents. This study's aims were to develop an innovate knowledge-building application and provide health services to prevent sexually transmitted diseases and unplanned pregnancies among this particular ethnic group.

\section{Methods}

The R\&D method utilized qualitative and quantitative approaches. The study was carried out in three phases as follows.

Phase 1: The situation of Akha adolescents within the education system was explored following a qualitative research design. Collected data were used to develop the mobile web application.

Phase 2: The designed and developed mobile web application was tested.

Phase 3: The testing of the developed mobile web application for evaluation from users in order the make improvements. The users made suggestions about knowledge presented, satisfaction with using the application, and users' own opinions.

\section{Participants}

The population for this research was 108 female and male adolescents of the Akha ethnic group, aged between 10-19 years, both in and outside the education system and living in Chiang Rai Province, Thailand. They were selected through purposive sampling and meeting the following requirements.

Inclusion Criteria for the study

1. Participants needed to have their own mobile phone or access to a mobile phone of another family member.

2. Participants needed to be able to understand, speak, read, and write in the Thai or Akha language.

3. Participants needed to be able to read, hear and use both hands.

Discontinuation criteria for the study

1. A participant lost their phone.

2. A participant wished to leave the research project.

Three phases of the study were designed as follow. 
Phase 1 was a survey of 42 adolescents (22 males, 20 females), divided into two groups: those following formal education and those following non-formal education. Each group consisted of 21 adolescents (11 males, 10 females).

Phase 2 was the designing and development of the mobile web application prototype which was tested on a similar group of 10 adolescents (5 males, 5 females) and 27 adolescents (12 males and 15 females).

Phase 3 was the actual testing on the sample of 108 users.

\section{Methods of data collection and data analysis}

Phase 1 was a survey and study of the context of Akha adolescents both in and outside the educational system (following an exploratory qualitative research design) using semi-structured interviews. A total of 42 participants (22 males, 20 females), were divided into two groups: the first group comprising adolescents following formal education and the second group adolescents following non-formal education. Each group consisted of 21 people (11 males, 10 females). Semi-structured interviews were used. Data was taped and transcribed individually and in groups and analyzed by content analysis.

Phase 2 was the design and development of the mobile web application prototype which was tested on similar groups, one consisting of 10 adolescents (5 males, 5 females) and the other consisting of 27 adolescents (12 males and 15 females). Data were recorded and the mobile web application prototype was developed after analyzing the data.

Phase 3 was a pre and posttest given to the sample of 108 Akha adolescents about knowledge of sexually transmitted diseases, unwanted pregnancy prevention and sexual health and the social questionnaires survey of the users' satisfaction and their opinions about the mobile web application. The questionnaires were given to all respondents in order to obtain data. The data were analyzed using a ready-made statistical program. Descriptive statistics were used distributing frequency, percentage, mean and standard deviation including a statistical paired samples t-test.

\section{Results}

The findings of the study can be classified under two headings as follows: the development of the mobile web application and its evaluation.

\section{The development of the mobile web application}

The development of the mobile web application included three phases:

Phase 1: exploring the needs of the Akha adolescents concerning knowledge of sexually transmitted diseases, prevention of unwanted pregnancies and sexual health;

Phase 2: the designing and development of the mobile web application; 
Phase 3: evaluation of the mobile web application's performance.

From the information gathered from phase 1 it was found that Akha adolescents needed knowledge about sexually transmitted diseases, unwanted pregnancy prevention and sexual health from health care providers because they were living in a remote area with limited access to health care. Therefore, a mobile web application was useful for them.

In phase 2 the mobile web application was designed and developed according to the needs of the Akha adolescents (as shown in Fig. 1). It was systematically designed with mechanisms within the functional structure.

Users can access from the mobile web based learning interface (MWLI) to interactive learning module (ILM) section to access education in the form of animated lessons and in the form of narratives through characters the Akha adolescents can relate to. Male and female learners receive different ILMs. In addition, students can access conditional learning topic (CLT) in two ways: direct access; and searching via a word or a topic of interest. With direct access users can study and find out more about what is presented in an easy-to-understand manner through data graphics. Using the search application users can search for information via a word or an area of interest, such as "pus" or "bleeding". The application will then present the relevant CLT to the user. In addition, it can provide birth control reminders and notifications to prevent unwanted pregnancies and sexually transmitted diseases through proactive monitoring and notification (PMN) mechanisms and display results via mobile notification interface (MNI).

Phase 3 reports the evaluation of the mobile web application under three headings: 1) measuring the Akha adolescents' knowledge of sexually transmitted diseases, unwanted pregnancy prevention, and sexual health before and after using the application; 2) satisfaction with the mobile web application; 3 ) opinions and recommendations from the users of the mobile web application.. Details are as follows.

\section{1) Measuring the users' knowledge before and after using the mobile web application}

Before the experiment, a total of 108 participants were tested to measure their knowledge of sex, specifically following: unplanned pregnancies, and sexually transmitted diseases and their prevention. The rest of the 108 participants were given a further test of knowledge measurement after using the developed innovative application. Data analysis, using reference statistics to test the statistical hypothesis to compare the differences between the mean of the pre and posttest, revealed that the sample group had a greater knowledge of sexual health, unplanned pregnancy; sexually transmitted diseases; and their prevention. There was a statistically significant increase as shown in Table 1. 
Table 1

Test scores measuring knowledge of sexual health, unplanned pregnancy, sexually transmitted diseases, and their prevention

\begin{tabular}{|c|c|c|c|c|c|c|}
\hline Test & Number of Participants & $\overline{\mathbf{x}}$ & S.D. & $t$ & $d f$ & $p$ \\
\hline Pretest & 108 & 4.15 & 1.36 & \multirow[t]{2}{*}{9.502} & \multirow[t]{2}{*}{108} & \multirow[t]{2}{*}{$<0.0001$} \\
\hline Posttest & 108 & 7.23 & 3.01 & & & \\
\hline
\end{tabular}

When analyzed by gender, it was found that the knowledge of sex and unplanned pregnancy, sexually transmitted diseases, and their prevention, of both male and female sample groups had statistically significant increased as shown in Table 2 and Table 3.

Table 2

Test scores measuring knowledge of sexual health, unplanned pregnancy, sexually transmitted diseases, and their prevention in the male group

\begin{tabular}{|c|c|c|c|c|c|c|}
\hline Test & Number of Participants & $\overline{\mathbf{x}}$ & S.D. & $t$ & $d f$ & $p$ \\
\hline Pretest & 50 & 3.85 & 0.57 & \multirow[t]{2}{*}{15.503} & \multirow[t]{2}{*}{108} & \multirow[t]{2}{*}{$<0.0001$} \\
\hline Posttest & 50 & 6.89 & 1.21 & & & \\
\hline
\end{tabular}

Table 3

Test scores measuring knowledge of sexual health, unplanned pregnancy, sexually transmitted diseases, and their prevention in the female group

\begin{tabular}{|lllllll|}
\hline Test & Number of Participants & $\overline{\mathbf{x}}$ & S.D. & $\boldsymbol{t}$ & $\boldsymbol{d f}$ & $\boldsymbol{p}$ \\
\hline Pretest & 58 & 4.45 & 1.98 & 9.169 & 108 & $<0.001$ \\
\cline { 1 - 4 } Posttest & 58 & 7.57 & 1.53 & & & \\
\hline
\end{tabular}

\section{2) Satisfaction with the use of the mobile web application}

Satisfaction with the developed mobile web application was assessed through a questionnaire under four headings: 1 ) learning; 2 ) ease of use; and 3 ) display of information. The findings are summarized and shown in Table 4. 
Table 4

Satisfaction with the use of the mobile web application

\begin{tabular}{|llll|}
\hline Areas of satisfaction & $\overline{\mathbf{x}}$ & S.D. & Levels of Satisfaction \\
\hline Learning & 4.36 & 1.78 & Good \\
\hline Ease of Use & 4.29 & 2.23 & Good \\
\hline Information Display & 4.71 & 1.24 & Very Good \\
\hline
\end{tabular}

From Table 4, it can be seen that users were impressed with the display of information on the mobile web application the innovative applications that were designed and presented through stories that were related to the context of the user. The characters, costumes, dialogues, graphics, locations and situations were appreciated by the users in the learning process. The users felt that the application was easy to use because the design of this application utilizes a digital learning process which is different from conventional learning. Therefore, there is an emphasis on motivation during study at a high level. Also, before the development, of the mobile web application, the needs of the sample of real users was evaluated. This enhanced the developed mobile web application because it related directly to the users' experiences.

\section{3) Opinions and recommendations for the use of the mobile web application}

After the sample group had used the developed mobile web application, the participants expressed their opinions and recommendations in the questionnaires in terms of 1) usability; and 2) interest and attractiveness. The findings are summarized and shown in Table 5. 
Table 5

Opinions and recommendations for the use of innovative applications

\begin{tabular}{|c|c|c|}
\hline Aspects & Opinions & Recommendations \\
\hline \multirow[t]{9}{*}{ Usability } & \multirow{2}{*}{$\begin{array}{l}\text { - "I understand the things that were } \\
\text { never known before." }\end{array}$} & \multirow{3}{*}{$\begin{array}{l}\text { - "It should be available offline." } \\
\text { - "I want to have this system on Facebook as } \\
\text { well." }\end{array}$} \\
\hline & & \\
\hline & $\begin{array}{l}\text { - "I understand rather than study by } \\
\text { myself." }\end{array}$ & \\
\hline & - "I feel good and knowledgeable." & $\begin{array}{l}\text { - "I want it in Chinese language for other person } \\
\text { who really wants to learn." }\end{array}$ \\
\hline & - "I know about the prevention. & \multirow[t]{5}{*}{ - "The information must be more than this." } \\
\hline & $\begin{array}{l}\text { - I feel safer and know how to } \\
\text { prevent sexual intercourse." }\end{array}$ & \\
\hline & $\begin{array}{l}\text { - "I know how to clean my own } \\
\text { genitals." }\end{array}$ & \\
\hline & $\begin{array}{l}\text { - "I feel easy to use and easy to } \\
\text { understand." }\end{array}$ & \\
\hline & $\begin{array}{l}\text { - "I know a lot of things that I want } \\
\text { to know." }\end{array}$ & \\
\hline \multirow[t]{5}{*}{$\begin{array}{l}\text { Interesting } \\
\text { and } \\
\text { attraction }\end{array}$} & $\begin{array}{l}\text { - "I have fun and gain knowledge } \\
\text { about sex, sexual care and } \\
\text { protection. }\end{array}$ & \multirow{3}{*}{$\begin{array}{l}\text { - "There should be a Thai voice in the video as } \\
\text { well because some video clips cannot produce } \\
\text { Thai voice because some Akha cannot } \\
\text { understand Akha language, such as half Akha, } \\
\text { etc." } \\
\text {-"I want to have multiple languages." }\end{array}$} \\
\hline & \multirow{2}{*}{$\begin{array}{l}-" I \text { think if there were no people to } \\
\text { teach us something like this, we } \\
\text { would not know about it." }\end{array}$} & \\
\hline & & \\
\hline & $\begin{array}{l}-" Y e s, \text { I get more knowledge. It is } \\
\text { valuable for learning." }\end{array}$ & \multirow[t]{2}{*}{ - "They should make the system to run faster." } \\
\hline & $\begin{array}{l}\text { - "If it was taught like this in } \\
\text { everywhere and for everyone, they } \\
\text { may know more about sex, and it } \\
\text { helps making everyone prevent } \\
\text { infection." }\end{array}$ & \\
\hline
\end{tabular}

From Table 5, it is clear that the majority of the users benefited from the developed mobile web application. They could learn and understand things that were difficult to understand or which they hadn't known before. They were interested in and enjoyed using the mobile web application. The value of the mobile web application was that it can be used in different contexts and situations. In addition, users also suggested possibilities for further development such as adding more languages to support more user groups, and improving the system to enable it to run and respond faster.

\section{Discussion}


This research project revealed a number of important issues that can be analysed and discussed to provide various benefits and development perspectives as follow.

1. The mobile web application can be applied as a tool to provide automated information including searching for information and providing specific advice. It is one of the important mechanisms in work related to artificial intelligence and can be further enhanced by more efficient applications of artificial intelligence applications such as data mining, and machine learning.

2. The perception and processing of information in learning materials in the mobile web application developed in this project can provide communication for Akha adolescents users for the development of appropriate behaviors, knowledge and practices in the area of sexual health. All information and media in the mobile web application are presented in a reliable and compelling format to suit the user group.

3. The mobile web application was developed using digital technology. Apart from directly benefiting the user group following the objectives of the project, this application is also an important tool for more efficient use in self care in the area of sexual health. In medicine and public health, for example, it can be used to review knowledge or skills in training which underscores the importance of providing standardized services that can reduce time and expenses.

4. The developed mobile web application can be applied or used as a tool to promote an active learning process for learners, users, and related personnel to acquire greater knowledge through awareness, practice, and participation in various learning contexts.

In conclusion, the significance statistical results of users' knowledge improvement and their satisfaction with the study, was in line with the results of previous studies [10-12, 15-18]. In Guse et al. (2012), for instance, it was found that new digital media can help to improve the sexual health of adolescents such as delaying first experiences of sex, motivating users of social networks, and helping them to learn about HIV, sexually transmitted infections, and pregnancy. Brayboy et al. (2017) also revealed that users of the application have significantly increased their knowledge on topics such as relationships and sexually transmitted diseases.

\section{Conclusion And Recommendation}

Because of the problems and severity of sexually transmitted diseases and unplanned pregnancies among Akha adolescents, the aims of this research were to develop an innovative application to serve as an important tool for enhancing knowledge and understanding of sexual health. This innovative application allows users to search for knowledge and practices or information about how to treat basic symptoms in order to prevent future transmission of sexually transmitted diseases and unplanned pregnancies, as well as providing practical guidelines and being able to connect to local health care providers. This application helps to educate users through animated storytelling with various interactive characters, situations and contexts which Akha adolescents can relate to. In addition, the application functions can also be set up to provide regular notifications to users to raise awareness of safe sex, such

Page 10/18 
as the use of condoms and the use of birth control pills. Female users can also use the application to record their emergency contraceptive intake, one of the key factors in preventing an unwanted pregnancy.

From the research findings it was clear that the mobile web application enables Akha adolescent users to acquire a better understanding of sexual health, sexually transmitted diseases and unpredictable pregnancies. Akha adolescents were satisfied when using the innovative application. They said it was easy to operate and they could acquire new knowledge quickly.

Furthermore, the Akha adolescents said the design and layout of the system was effective and attractive. The learning module contained an interactive animated story, which enabled the Akha adolescents to have a good and effective experience while learning.

This research is not only beneficial and valuable to Akha adolescents due to the development of the mobile web application, but it is also useful for further research into application development in three ways:

1. The mobile web application in this research can be used as a model and extended to other ethnic groups in terms of learning styles and presentation through relatable contexts. For example, it could be used with other ethnic populations in remote areas such as hill tribe groups in different parts of Thailand.

2. The mobile web application can be used as a normal classroom teaching tool helping learners to increase their knowledge and understanding through interactions and presentations in relevant and dialectic contexts.

3. Information arising from the use of this innovative application makes users aware of how to protect themselves and prevent unwanted pregnancies and sexually transmitted diseases.

\section{Abbreviations}

ILM: Interactive Learning Module; CLT: Conditional Learning Topic; PMN: Proactive Monitoring and Notification; MWLI: Mobile Web-based Learning Interface; MNI: Mobile Notification Interface.

\section{Declarations}

\section{Ethic approval and consent to participate}

This study was reviewed and approved by the Research Ethics Committee, Public Health Office of Chiang Rai Province. All participants agreed to participate prior to the implementation of the study and written consent forms had been signed by parents of all participants.

\section{Consent for publication}

Not applicable 
Availability of data and materials

The data generated and analyzed during the current study are available from the author on reasonable request. The questionnaires used in this study were developed only for this purpose.

\section{Competing interests}

The authors declare that they have no competing interests.

\section{Funding}

This research was funded by the National Research Council of Thailand and the Center of Excellence for The-Hill-Tribe Health Research of Mae Fah Luang University.

\section{Author's contributions}

SC designed the study and performed the statistical analysis. CW participated in the design of the study and helped to draft the manuscript. All authors read and approved the final manuscript.

\section{Acknowledgements}

The author is grateful for support from the School of Nursing and the Center of Excellence for the-HillTribe Health Research of Mae Fah Luang University and the National Research Council of Thailand.

\section{References}

1. Bureau of Reproductive Health, Department of Health: Live birth rate among women aged 10-14 years. http://rh.anamai.moph.go.th/ewt_dl_link.php?nid=151 (2017). Accessed Nov, 2017

2. Department of Disease Control: Reproductive health situation in adolescents. http://rh.anamai.moph.go.th/download/all_file/brochure/FinalAW.pdf (2017). Accessed Nov, 2017

3. Office of the Health Promotion Foundation: worrying situation Thai adolescents are more infected with HIV. http://www.thaihealth.or.th/Content/41145 (2017). Accessed July, 2017

4. Bureau of Reproductive Health, Department of Health: Live birth rate among women aged 10-14 years. http://rh.anamai.moph.go.th/ewt_dl_link.php?nid=152 (2017). Accessed Nov, 2017

5. Kovavisarach E, Chairaj S, Tosang K, Asavapiriyanont S, Chotigeat U. Outcome of teenage pregnancy in Rajavithi Hospital. Medical journal of the Medical Association of Thailand. 2010;93(1):1-8.

6. Ganchimeg T, Ota E, Morisaki N, Laopaiboon M, Lumbiganon P, Zhang J, et al. Pregnancy and childbirth outcomes among adolescent mothers: a World Health Organization multicountry study. BJOG. 2014;121:40-8. https:// doi.org/10.1111/1471-0528.12630.

7. Hoirat $P$, Wongsawat $P$. Thai adolescents and premature sex. Phrapokklao College of Nursing journal. 2017; 28(2): 173-182. 
8. Buhi ER, Daley EM, Oberne A, Smith SA, Schneider T, Fuhrmann HJ. Quality and accuracy of sexual health information web sites visited by young people. J Adolesc Health. 2010; 47(2):206-8. https://doi.org/10.1016/j.jadohealth.2010.01.002.

9. Leanza F, Hauser D. Teens, technology, and health care. Prim Care. 2014; 41(3):559-66. https://doi.org/10.1016/j.pop.2014.05.006.

10. Guse K, Levine D, Martins S, Lira A, Gaarde J, Westmorland W, Gilliam M. Interventions using new digital media to improve adolescent sexual health: a systematic review. J Adolesc Health. 2012;51(6):535-43. https://doi.org/10.1016/j.jadohealth.2012.03.014.

11. Chavez NR, Shearer LS, Rosenthal SL. Use of digital media technology for primary prevention of STIs/HIV in youth. J Pediatr Adolesc Gynecol. 2014;27(5):244-57. https:// doi.org/10.1016/j.jpag.2013.07.008.

12. Dunne A, Mclntosh J, Mallory D. Adolescents, sexually transmitted infections, and education using social media: A review of the literature. J Nurse Pract. 2014; 10(6):401-8. https://doi.org/10.1016/j.nurpra.2014.03.020.

13. Wong CA, Merchant RM, Moreno MA. Using social media to engage adolescents and young adults with their health. Health Care. 2014;2(4):220-224. https://doi.org/10.1016/j.hjdsi.2014.10.005

14. Bull SS, Levine DK, Black SR, Schmiege SJ, Santelli J. Social media-delivered sexual health intervention: a cluster randomized controlled trial. Am J Prev Med. 2012;43(5):467-74. https://doi.org/10.1016/j.amepre.2012.07.022.

15. Brayboy LM, Sepolen A, Mezoian T, Schultz L, Landgren-Mills BS, Spencer N, et al. Girl talk: a smartphone application to teach sexual health education to adolescent girls. J Pediatr Adolesc Gynecol. 2017; 30(1):23-8. https:// doi.org/10.1016/j.jpag.2016.06.011.

16. Mac Callum K, Jeffrey L. Kinshuk. Comparing the role of ICT literacy and anxiety in the adoption of mobile learning. Comput Human Behav. 2014; 39:8-19. https://doi.org/10.1016/j.chb.2014.05.024

17. Morales R, Igler B, Böhm S, Chitchaipoka P. Context-aware mobile language learning. Procedia Comput Sci. 2015; 56:82-7. https:// doi.org/10.1016/j.procs.2015.07.198.

18. Xu, Wu, Daneshmand, Liu, W. A data privacy protective mechanism for WBAN. Wireless Communications and Mobile Computing. 2015; http://doi.org/10.1002/wcm.

19. Apidechkul T. Sexual behaviors and seroprevalence of HIV, HBV, and HCV among hill tribe youths of Northern Thailand. BMC Public Health. 2019; 19(1):1101. https:// doi.org/10.1186/s12889-019-74599.

\section{Figures}

\section{Figure 1}


An overview of the working structure within the mobile web application

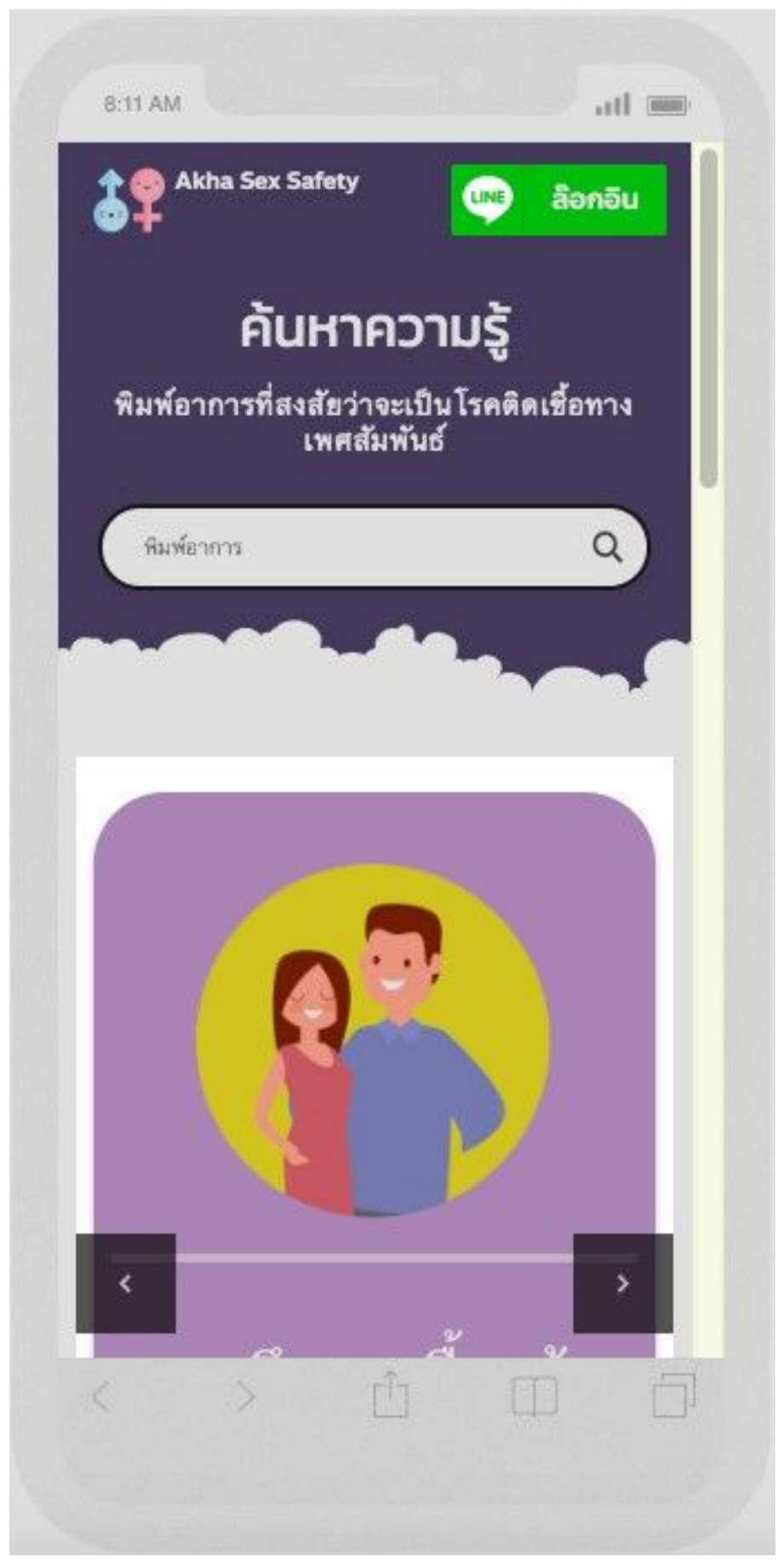

Figure 2

Example of the first page of the mobile web application that can be used to search according to symptoms or for accessing various lessons 


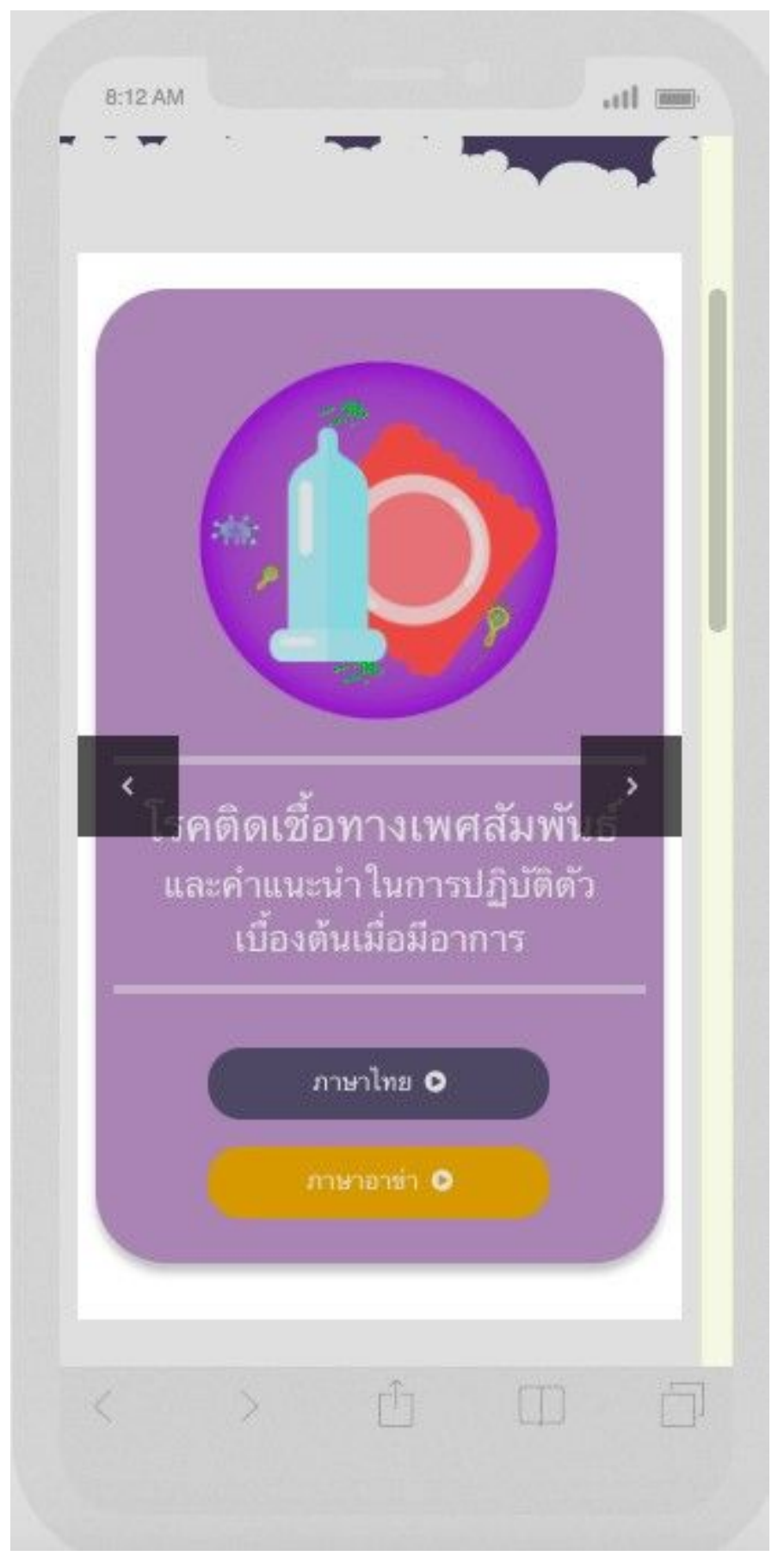

\section{Figure 3}

Example of a page showing the language selection menu for the lesson 


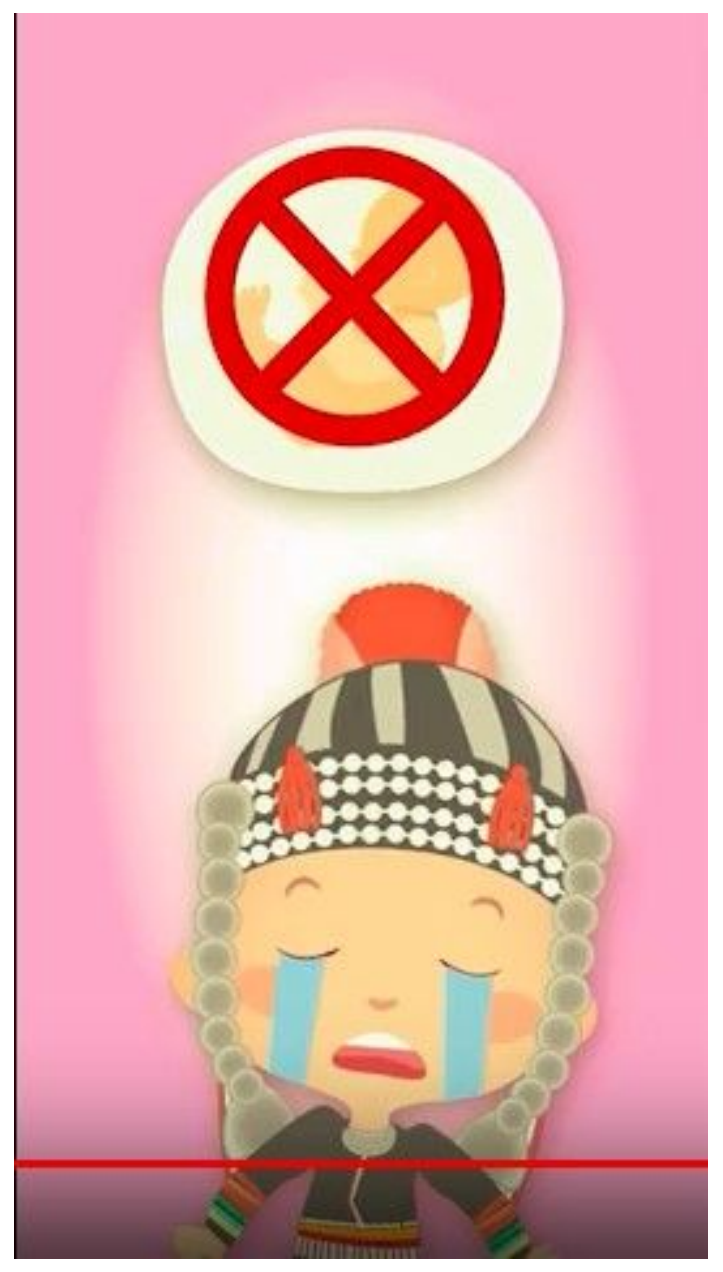

\section{Figure 4}

Example of animation in a lesson presented with characters in Akha ethnic costumes and with audio narration in Akha 


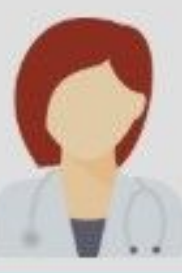

\section{วิธีกิบยาคุบกำเบิดชนิล 21 เบ็ก}

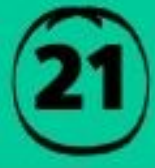

(8) ให้เรี่บกินเบ็ลแรกกายในว้นกี่ $1-5$ ของการ ปีประจำเดือน โลยกินตาบลูกศรกุกวันจน หนลแผง ควรกิบเวลาเลียวกัน เช่น ก่อน uอนกอนกลาטคืแนเพื่อเ่วยลลอาการคลื่นไส้ วาเจียน เนื่อกินหนกแผจแล้วให้เว้น 7 วัน ช่วงกี่เว้นก็จะเีประจำเลือนอวกบา

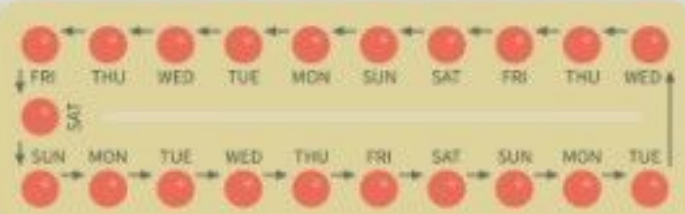

\section{Figure 5}

Example of an illustration which explains how to take birth control pills

\section{Figure 6}

Example of a page which shows how to contact hospitals 


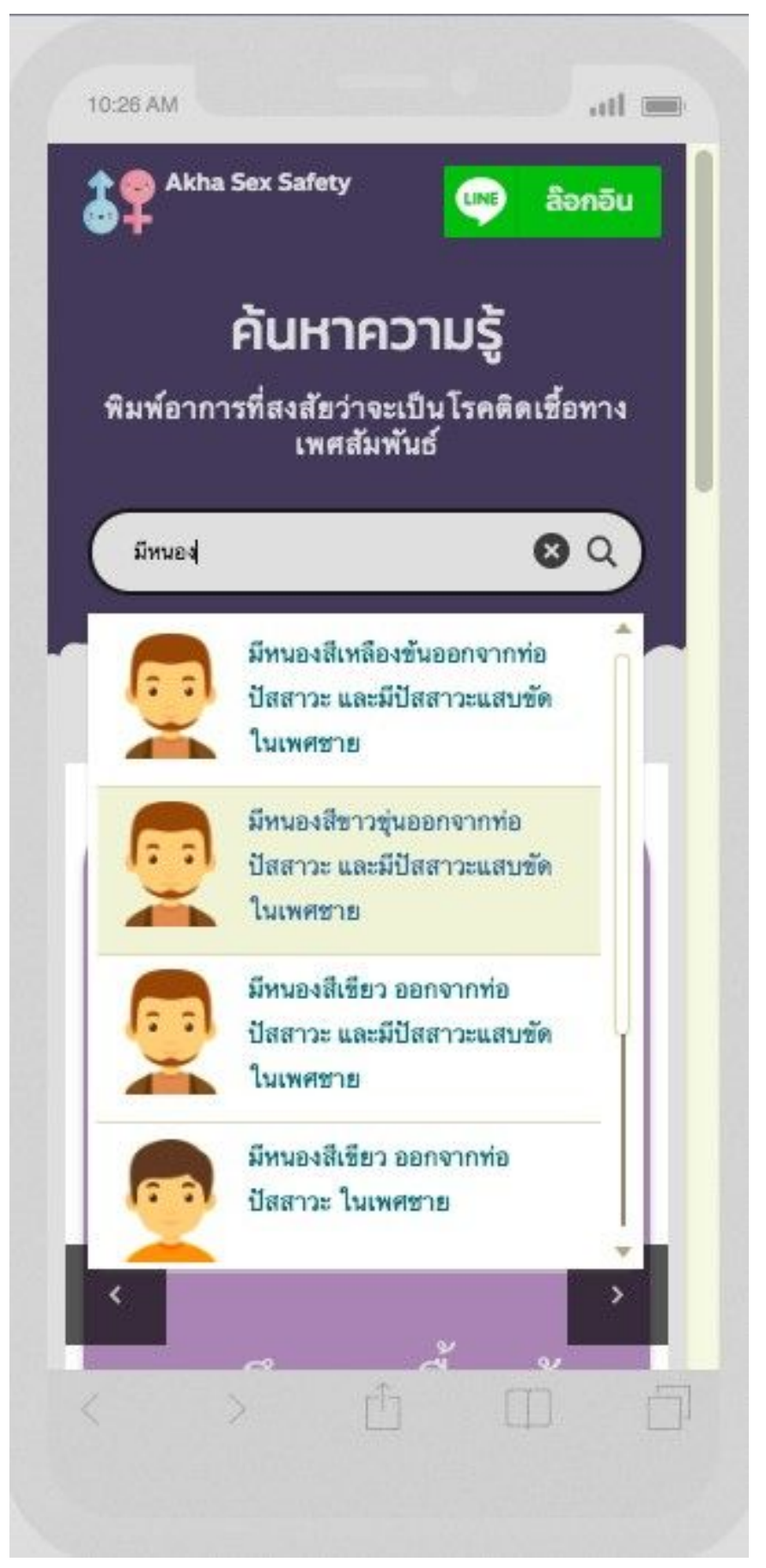

Figure 7

Example of a search option page providing access to self care practice and initial treatment guidelines among males

\section{Supplementary Files}

This is a list of supplementary files associated with this preprint. Click to download.

- Questionnaires.docx 